\title{
Linking biodiversity indicators, ecosystem functioning, provision of services and human well-being in estuarine systems: Application of a conceptual framework
}

\author{
Rute Pinto $^{\mathrm{a}, *}$, Victor N. de Jonge ${ }^{\mathrm{b}}$, João Carlos Marques ${ }^{\mathrm{a}}$ \\ a IMAR - Institute of Marine Research, Department of Life Sciences, Faculty of Sciences and Technology, University of Coimbra, 3004-517 Coimbra, Portugal \\ ${ }^{\mathrm{b}}$ IECS - Institute of Estuarine and Coastal Studies, University of Hull, Hull HU6 7RX, United Kingdom
}

\section{A R T I C L E I N F O}

\section{Article history:}

Received 30 May 2013

Received in revised form 9 September 2013

Accepted 12 September 2013

\section{Keywords:}

Ecosystem approach

Biodiversity-Ecosystem functioning

Ecosystem services

Holistic approach

Estuaries

\begin{abstract}
A B S T R A C T
Assuming that human well-being strongly relies on the services provided by well-functioning ecosystems, changes in the ecological functioning of any system can have direct and indirect effects on human welfare. Intensive land use and tourism have expanded in recent decades along coastal ecosystems, together with increasing demands for water, food and energy; all of these factors intensify the exploitation of natural resources. Many of the interrelations between ecosystem functioning and the provision of ecosystem services (ES) still require quantification in estuarine systems. A conceptual framework to assess such links in a spatially and temporally explicit manner is proposed and applied to the Mondego estuary (Portugal). This framework relies on three consecutive steps and discriminates among biodiversity structural components, ecosystem functioning and stability and the services provided by the ecosystem.
\end{abstract}

Disturbances in abiotic factors were found to have a direct effect on biodiversity, ecosystem functioning and the provision of ES. The observed changes in the species composition of communities had a positive effect on the ecosystem's productivity and stability. Moreover, the observed changes in the estuarine ES provision are likely to arise from changing structural and abiotic factors and in the present case from the loss or decline of locally abundant species. This study also indicates that linear relationships between biodiversity, ecosystem functioning and services provision are unlikely to occur in estuarine systems. Instead, cumulative and complex relations are observed between factors on both temporal and spatial scales. In this context, the results suggest several additional conclusions: (1) biodiversity and ecosystem functioning interaction with human well-being need to be incorporated into decisionmaking processes aimed at the conservative management of systems; (2) the institutional use of research results must be part of the design and implementation of sustainable management activities; and (3) more integrative tools/studies are required to account for the interactions of estuarine ecosystems with surrounding socio-economic activities. Therefore, when performing integrated assessments of ecosystem dynamics, it becomes essential to consider not only the effects of biodiversity and ecosystem functioning on services provision but also the effects that human well-being and ES provision may have on estuarine biodiversity and ecosystem functioning.

The proposed framework implies taking into account both the functional and the commodities points of view upon natural ecosystems and by this representing a line of thought which will deserve further research to explore more in detail the conceptual links between biodiversity-ecosystem functioning-services provided.

(C) 2013 Elsevier Ltd. All rights reserved.

\section{Introduction}

Ecosystems deliver services of great value to human society (Pearce and Moran, 1994; Costanza et al., 1997; Daily, 1997; Barbier et al., 2011; Burkhard et al., 2012). However, increasing

\footnotetext{
* Corresponding author. Tel.: +351 239836386; fax: +351239823603.

E-mail address: rutepinto@ci.uc.pt (R. Pinto).
}

anthropogenic pressures have led to a growing loss of biodiversity and changes in the internal functioning of ecosystems, reflected in the variation of benefits provided to human societies (Hooper et al., 2005). In 2005, the Millennium Ecosystem Assessment (MEA, 2005) published the status of ecosystems and their capacity to benefit humans, concluding that most of the world's wetlands have been destroyed or degraded during the 20th century, thereby creating the need for integrative frameworks to consider the dynamics of whole systems. The central framework 
for this assessment (MEA, 2003) was a simple conceptual guiding principle:

biodiversity $\rightarrow$ ecosystem

vices $\rightarrow$ human well-being ser-

where each arrow represents a causal relationship (Naeem et al., 2009) and where ecosystem services (hereafter ES) may be seen as functions that ultimately benefit humans (Costanza et al., 1997; Daily, 1997; Naeem et al., 2009). This framework relies on the assumption that increased biodiversity augments, at least to a certain extent, ecosystem functioning, which improves ES and may eventually improve human well-being, depending on the elements involved. A number of studies have attempted to link explicitly or implicitly the biological composition of ecosystems, given by biodiversity proxies, to the stability of ecosystem functioning (e.g., Remane, 1934; MacArthur, 1955; Odum, 1959; May, 1972; de Jonge, 1974; Pimm, 1984; Ives et al., 1999; Loreau et al., 2001; Balvanera et al., 2006; Isbell et al., 2009; Godbold et al., 2011). These studies assumed that such links may have a determinant role in ES delivery (e.g., Costanza et al., 1997; Turner et al., 2003; Srivastava and Vellend, 2005; Tilman et al., 2006; Díaz et al., 2007; HainesYoung and Potschin, 2010). Typically, researchers have considered that if ecosystem biodiversity could be linked with functioning then it would follow that ES are directly related to human well-being (Naeem et al., 2009).

Although most of the considerations of ES focus on the link between ecological functions and human well-being, it is also important to consider the prior link between biodiversity and ecosystem functioning (Morling et al., 2010). Several studies have tried to demonstrate the biodiversity role in ES provision (Mace and Bateman, 2011), through: (1) biodiversity supports the delivery of ES (Díaz et al., 2006), acting as insurance against change (increased redundancy associated with higher diversity may buffer ecosystems against change, contributing to higher system resilience) (Ulanowicz, 1979; Hooper et al., 2005) and offering more options for the future (Yachi and Loreau, 1999); (2) genetic and biological species diversity may directly supply some goods, such as animal and plant breeds (MEA, 2003); and (3) many components of biodiversity are valued by people for altruistic reasons (e.g., appreciation of wildlife, contribution to spiritual or educational motifs and recreational experiences), although biodiversity, per se, is not considered to be a service by everyone (Haines-Young and Potschin, 2010). Thus, when addressing natural resources management, the challenging issues are determining the nature and sensitivity of the relationship between environmental quality/biodiversity assets and the provision of services. Most of this discussion regards the links between biodiversity assets and ecosystem functioning and stability, which can be used as a proxy to the supporting services classes from the MEA, or intermediate services. Several studies have been conducted to address the relation between biodiversity assets and ecosystem productivity and stability (e.g., Pimm, 1984; Schwartz et al., 2000; Loreau et al., 2001; Tilman et al., 2005; Balvanera et al., 2006); nevertheless, the controversy persists.

To address these complex relations, the Convention for Biological Diversity (2004) suggested the use of the ecosystem approach (EA) to provide a clear integration into a holistic framework of all services provided to people by biodiversity and ecosystems. This approach defends an integration of the ecological, economic, and socio-cultural perspectives when evaluating an ecosystem (de Groot et al., 2002; Farber et al., 2002; MEA, 2005; Carpenter et al., 2009), thus providing a methodological framework for wetland management (de Jonge, 2007). In fact, ES clearly have ecological and socio-economic aspects whose interdependencies need to be clarified (Mace and Bateman, 2011) and described (de Jonge et al., 2012). Therefore, it is crucial to understand the role and effects of biodiversity in both an ecological as well as a socioecological context (Carpenter et al., 2009). Despite the attempts to identify the potential relationships between biodiversity and the delivery of services, adequate quantitative data are not available (Norris et al., 2010). Despite the few data there is some evidence for a weak correlation between areas rich in biodiversity (according to nature conservation designations) and those high in ES delivery (Naidoo et al., 2008; Anderson et al., 2009). A study by Norris et al. (2010) supports the idea that microorganisms, fungi and plants play a major role in supporting and regulating services, whereas vertebrates are more important for cultural services, described as the 'cute and cuddling' services in de Jonge et al. (2012). Because of the increasing pressures on natural resources, trade-offs among services have to be verified. The general increase in provisioning services over the past century has been achieved through decreases in regulating and cultural services and in biodiversity (MEA, 2005; Bennett and Balvanera, 2007; Carpenter et al., 2009). In this context, it is essential that such trade-offs are recognised in future ecosystem assessments (Carpenter et al., 2009). The suggestion to further clarify the relations between habitats, food web functioning via ecological network analysis (ENA) and the Driver-Pressure-State Change-Impact-Response (DPSIR) approach as performed by de Jonge et al. (2012) may be seen as a step in that direction.

Because of the complexity and integration of concepts and methodologies, it is essential to clearly define the terms used in the present work:

(a) Biodiversity is the variability among living organisms and their habitats from all sources, including diversity within species, between species and within entire ecosystems (Heywood, 1995). Because of data limitations in the present case, diversity measures were used to estimate biodiversity (according to Marques, 2001);

(b) Ecosystem functioning refers to all of the biogeochemical processes occurring within an ecosystem, such as the cycling of nutrients, matter or energy (Naeem, 1998);

(c) Ecological condition refers to the integrity of the ecosystem (Jorgensen et al., 2010); in the present study, ecological condition was expressed as the ecological quality status sensu the European Union Water Framework Directive (EC, 2000);

(d) Stability is a collective notion defined by three properties (constancy, resilience and persistence) (sensu Grimm and Wissel, 1997); in the present study, stability was expressed as temporal stability (see Pinto et al., 2013a);

(e) Ecosystem services can be defined as the functions of ecosystems having value for human welfare (Fisher et al., 2009). According to the MEA (2005), ES can be classified into one of four categories: regulating (e.g., water purification); supporting (e.g., nutrient cycling); provisioning (e.g., food production); and cultural (e.g., opportunities for recreation); and

(f) Human well-being can be defined as the human experiences that include the basic materials for human lives, freedom of choice, health, good social relations, a sense of 'cultural identity' and security (MEA, 2005; Díaz et al., 2006).

The present work discusses the links between biodiversity proxies and ecosystem functioning in estuarine ecosystems, the role of macro-invertebrates in the provision of ES, and the use of ES as a tool to address the exploitation and conservation of natural resources. Therefore, the present work provides clues regarding the changes in estuarine biodiversity that are expected to have consequences for human well-being. In a first step, the effect of biodiversity assets on several ecosystem processes was analysed. In a second step, the relation between those processes and the capacity of the system to provide services (as a link to the socio-economic system) was considered. Finally, recommendations based on this 
integration identified gaps in current knowledge of estuarine functioning and future research needs. Five main objectives were outlined under these three main research steps:

Step 1: Linking estuarine biodiversity to ecosystem functioning

1. To evaluate the performance of biodiversity structural proxies (e.g., number of species) and their relationships to functional indicators.

\section{Step 2: Linking ecosystem functioning to services}

1. To assess how measures of functional diversity (e.g., macrobenthic productivity) perform under different ecological status classifications;

2. To explore the relation between ecosystem functioning and estuarine stability; and

3. To analyse and understand the link between biodiversity proxies and ES supply.

\section{Step 3: Linking changes in services to human well-being}

1. To estimate how the achieved knowledge on biodiversity and ecosystem functioning can be used to improve ES provision and consequently human well-being.

\section{Methodology}

\subsection{Study site description and sampling protocol}

The Mondego estuary is an intertidal warm-temperate ecosystem consisting of a North and a South arms separated by Murraceira Island (Fig. 1). The two arms of the estuary have very different characteristics, constituting two distinct subsystems. The North arm contains impoverished benthic communities as compared to the South one. The North arm is relatively deep (5-10 m during high tide) and presents stronger tidal salinity changes (the freshwater flows mainly through this arm). The bottom sediments consist mainly of medium to coarse sand. In addition, the North arm is the principal navigation channel, supporting the harbour of Figueira da Foz. Due to this function this channel is dredged regularly. The South arm is shallow (2-4 m during high tide) and has a predominantly sandy to muddy channel bed. Up to recently (2006) the upstream communication with the North arm and the main river course has been almost cut off by strong sedimentation of muddy material. As a consequence, the water circulation in the South arm was mainly dependent on the combination of tides and the freshwater inflow of a tributary, the Pranto River (Flindt et al., 1997; Marques et al., 2003). The freshwater discharge there is artificially controlled by a sluice. Almost $75 \%$ of the area of the South arm consists of intertidal mudflats which exposed during low tide (Neto et al., 2008).

In the early 1990s, when upstream communication between the two arms was completely interrupted, the combined effects of increased water residence time in the South arm (ca 9 days) and increased nutrient concentrations led to seasonal blooms of Ulva spp. along with a concomitant severe reduction of the Zostera noltii meadows (Martins et al., 2001), which was previously the richest habitat in terms of productivity and biodiversity (Marques et al., 2003; Patrício et al., 2004). The entire Mondego estuary is under permanent anthropogenic pressure, which drives its development as an ecosystem (Marques et al., 2003; Pinto et al., 2010). First, the surrounding area supports many economic activities, which vary from extractive activities (e.g., agriculture and salt production) to on-site activities (e.g., leisure and tourism). Patently, this panoply of uses influences the ecological condition and performance of the estuarine communities (Pinto et al., 2010). In addition, the system also provides a wide range of ecosystem goods, such as the capture of bivalves and fish.

Previous studies considering the estuarine salinity gradient and subtidal soft-bottom characteristics described four distinct habitats in the Mondego's lower estuary (Fig. 1): euhaline estuarine sand (EE), north arm polyhaline sand (PS), south arm polyhaline sand (PSM), and south arm polyhaline muddy sand (PMS) (Teixeira et al., 2008). Additionally, data was grouped aiming to cover the South arm (SA) subsystem and to look at the Mondego estuary (ME) as a whole.

In each of these habitats, subtidal benthic communities have been regularly monitored following standardised protocols since the early 1990s. In the present work, data from sampling performed in the spring of 1998, 2005, 2006 and 2007 was used. In each year, five sediment replicates were randomly collected from each habitat using a van Veen grab with a $0.078 \mathrm{~m}^{2}$ dredging area. The samples were immediately sieved through a $0.5 \mathrm{~mm}$ mesh gauze and preserved in a $4 \%$ formalin solution. Production estimates were performed in all seasons (spring, summer, autumn, winter) following the same protocol. In the field, abiotic parameters were measured (e.g., $\% \mathrm{O}_{2}, \mathrm{O}_{2}$, salinity, temperature). In the laboratory, the biological samples were washed through a sieve of $1.0 \mathrm{~mm}$, sorted and the species identified to the lowest possible taxonomic level, preferably the species level. Once identified and counted, the biomass was estimated as ash-free dry weight $\left(\mathrm{g} \mathrm{AFDW} \mathrm{m}^{-2}\right.$ ) by drying the samples to a constant weight at $60^{\circ} \mathrm{C}$ and ashing them at $450^{\circ} \mathrm{C}$ for $8 \mathrm{~h}$. Nutrient concentrations in the water column (ammonium, nitrite, nitrate and phosphate), total suspended solids (TSS), chlorophyll-a and particulate organic matter (POM) contents and sediment properties (e.g. \% organic matter (OM), \% coarse sand, \% fine sand, \% mud) were estimated in the laboratory, following standard methods (Strickland and Parsons, 1972; Limnologisk Metodik, 1992).

\subsection{Framework adopted}

A three-step approach was applied (Fig. 2) to estimate the successive relationships linking biodiversity, ecosystem functioning, estuarine stability, ES and human well-being. Structured on existing frameworks and indicators, this approach aims to translate field measurements to social and economic standards using a multidisciplinary perspective. The Mondego estuary was used as a practical example of an ecosystem under pressure from both social drivers (e.g., increasing population density) and economic drivers (e.g., intense land occupation rates).

\subsubsection{Linking estuarine biodiversity to ecosystem functioning}

Three proxies for the biodiversity structure were considered and quantified: the number of species $(S)$, total abundance $(N)$, and total biomass. Several measures of diversity were calculated, including the Shannon-Wiener index $\left(H^{\prime}\right.$; Shannon and Wiener, 1963), the Margalef index (d; Margalef, 1958), and a multimetric integrative index (BAT; Teixeira et al., 2008). BAT integrates, in a cumulative index, three widely used metrics - Shannon-Wiener index, Margalef index and AMBI - which are based on different approaches when evaluating system status. This integration results from experience works on the Portuguese transitional and coastal waters systems that demonstrate that, when evaluating the system condition, the combination of several metrics is more accurate than any single metric (Pinto et al., 2009). The Shannon-Wiener index is a diversity measure that takes into account the proportional abundance of species; the Margalef index is based on the specific richness of a system; and the AMBI (Borja et al., 2000) relies on the distribution of species into five ecological groups (Grall and Glémarec, 1997), distributed according to their sensitivity to an increasing stress gradient (enrichment of organic matter) 


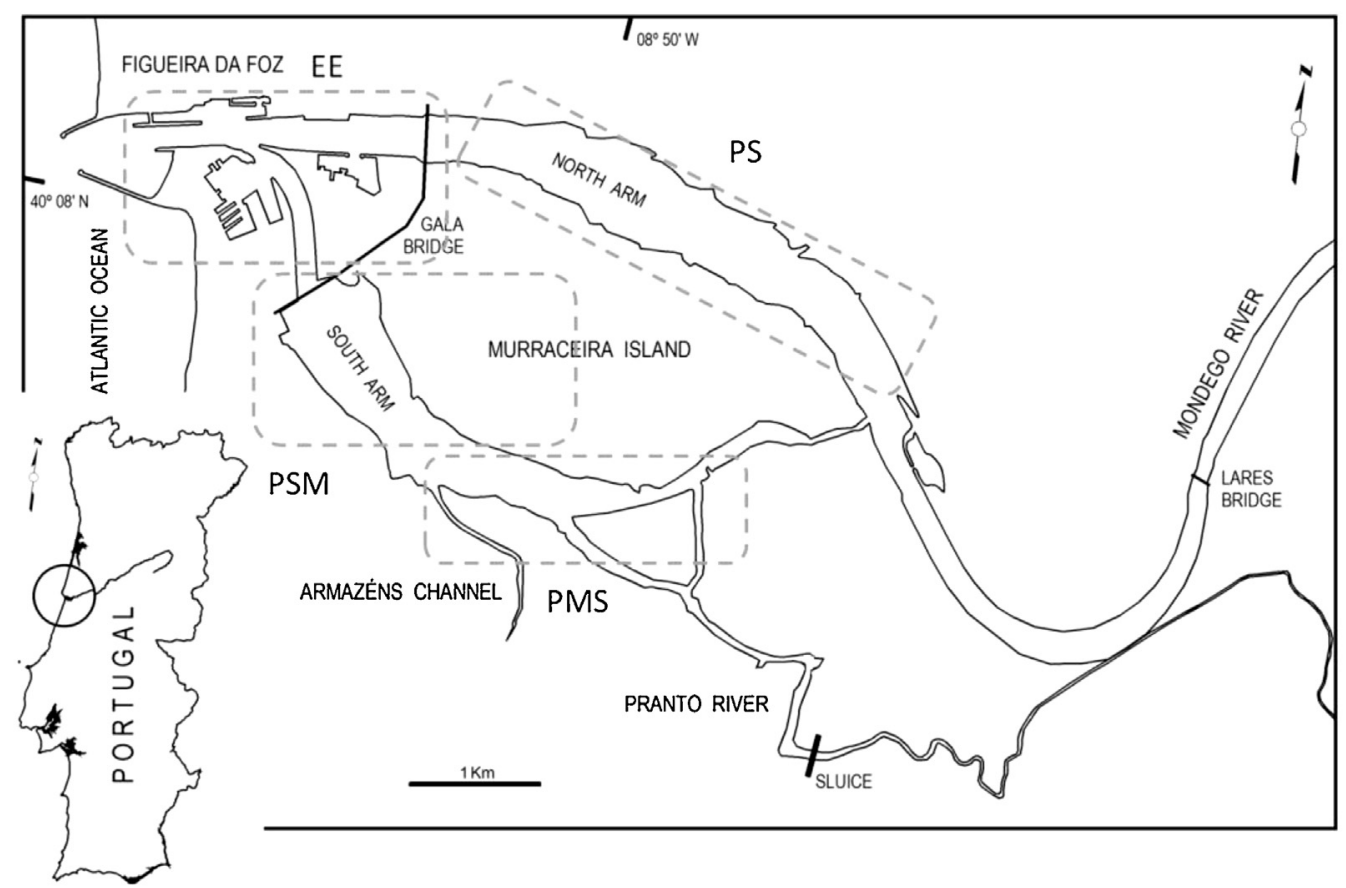

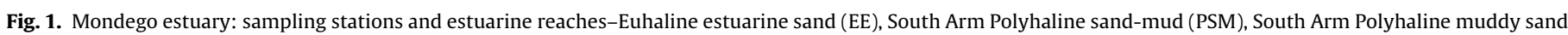
(PMS), and North Arm Polyhaline sand (PS).

(Glémarec, 1986). Overall index classifications can range between 0 (bad ecological quality) and 1 (good ecological quality) (Teixeira et al., 2008, 2009). Finally, based on BAT results, the Ecological Quality Status (EQS) was estimated following the requirements of the Water Framework Directive (WFD; EC, 2000).

\subsubsection{Linking ecosystem functioning with stability and services} provision

The role of macrobenthic functional diversity within the estuarine ecosystem was quantified by using two proxies:

(a) The feeding guilds composition for subtidal communities assigned each taxon to a feeding guild according to its feeding habit (carnivorous/omnivorous/grazers - G; surface deposit feeders - SDF; subsurface deposit feeders - sSDF; suspension feeders - SF) based on literature reviews (e.g., Fauchald and Jumars, 1979; Gaston, 1987; Garcia-Arberas and Rallo, 2002; Mancinelli et al., 2005). This proxy was calculated using the relative abundance of species in each trophic group and was expressed as a percentage.

(b) The macrobenthic productivity of the system was calculated based on Brey, 2001. The production/biomass (P/B) ratio (Margalef, 1963) was estimated using an empirical multiple non-linear model, which incorporated biomass data and biotic and abiotic parameters. The weight-to-energy ratios are needed for application of the empirical method, and the biomass estimates were converted into $\mathrm{KJ}$ using the conversion factors for major taxonomic groups proposed by Brey, 2001 (method version 4-04) (worksheet provided in Brey, 2001; www.awi-bremerhaven.de/Benthic/Ecosystem/FoodWeb/ Handbook/main.htm). This method has been used as an alternative empirical technique for the estimation of secondary production (after Cusson and Bourget, 2005; Dolbeth et al., 2005). Following the methodology of Brey et al. (1996), the P/B ratio was estimated by group (G; SDF; SSDF; and SF). Production was then calculated by multiplying the $\mathrm{P} / \mathrm{B}$ ratio by the average biomass. Because productivity changes are usually

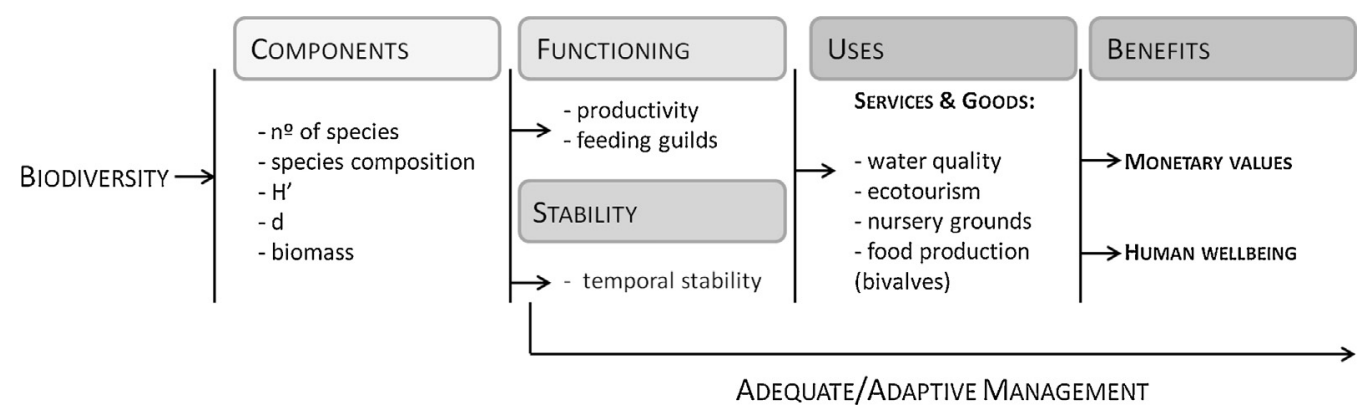

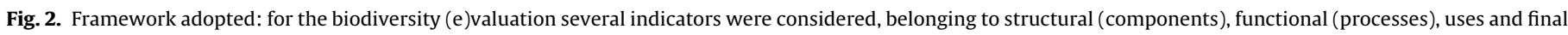

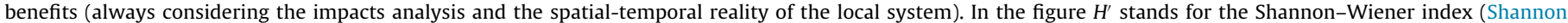

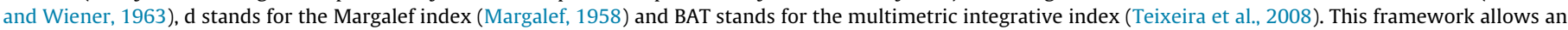

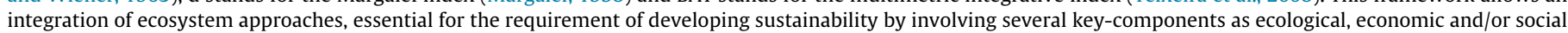
dimensions. 
reflected in the year following a particular condition, three years were used to estimate the estuarine production: 2005, 2006, and 2007. Only spring data were available for 1998 , so no production estimates could be computed for that year. Before estimating the productivity, the species constancy was calculated to measure the importance of species at each reach (Desroy et al., 2002). Constancy is given by Eq. (1) (Desroy et al., 2002):

$C_{i j}=\frac{n_{i j}}{n_{j}} \times 100$

where $n_{i j}$ is the number of occurrences of the species $i$ in the station of group $j$ and $n_{j}$ is the number of stations in group $j$. Characteristic species were categorised as either constant ( $C>50 \%$ ) or common $(50 \%<C>25 \%$ ) (Desroy et al., 2002). Those species observed for only one or two seasons per year were omitted from the data analysis.Estuarine temporal stability was used as a proxy for estuarine stability (see Pinto et al., 2013a). Tilman (1999) defined TS $\left(\mathrm{g} \mathrm{C} \mathrm{m}^{-2} \mathrm{y}^{-1}\right)$ as the variation in species biomass, which is quantified as the mean spring biomass $\left(\bar{b}, \mathrm{~g} \mathrm{C} \mathrm{m}^{-2}\right)$ divided by the standard deviation of community biomass production through time $\left(\sigma_{x i \rightarrow x j}, \mathrm{y}^{-1}\right)$ (Eq. (2)):

$\mathrm{TS}=\frac{\bar{b}}{\sigma_{x y \rightarrow x j}}$

Although it is not a process, TS measures the percentage of variation around the mean, for which larger values represent greater stability, i.e., lower temporal variation around the mean (Tilman, 1999). If there was no variation at all, the temporal stability would be maximal (infinite). When variation is large relative to the mean, the temporal stability is small (near 0) (Lehman and Tilman, 2000). TS measures relative stability for both non-equilibrium and near-equilibrium conditions (Tilman, 1999).

\subsubsection{Linking changes in services to human well-being}

Trends might be drawn based on the composition and functional roles of the species (e.g., structural or behavioural characteristics) occurring in an ecological system and possessing potential social interest (whether it has direct or indirect benefits). The relationships between abiotic indicators, biodiversity structural assets, and ecosystem functioning were tested using a Spearman correlation analysis $(r)$

The ES supply was used to estimate the link between the proxy for biodiversity-ecosystem functioning and the social importance of the estuarine ecosystem to human well-being (Fig. 2). Locally the bivalve catch activities has a very strong socio-economic function, therefore, to estimate the link between biodiversity and human well-being the condition of the bivalve population was considered (used as an example of the linkage between the system natural capital and human well-being). The flux of the estuarine services (ecosystem stocks and flows) can be measured, for example, as quantitative productivity over the years. For instance, the bivalves' biomass comprises a stock. This stock can then flow from the bivalve community into the catch of fisheries, which is the flow that is of value to society (Costanza et al., 2001). For the bivalve catch, two levels of potential interference were identified:

(1) At an individual level the available and harvestable biomass of the bivalve communities by hand, reflecting the surrounding environmental conditions, and the people who harvest it and earn additional income from the harvest (measured in tonnes of catch; data source: www.dgpa.min-agricultura.pt) and

(2) At an industrial level the industrial harvest, where the number of licensed boats, the catch (in tonnes), and the potential for greater interference with the ecosystem (data source: www.dgpa.min-agricultura.pt) were used as indicators.

Additionally, based on secondary data, the trends in services as the nursery ground capacity of the system, water quality and eco-tourism facilities were also analysed.

\section{Results}

\subsection{Linking estuarine biodiversity to ecosystem functioning}

The estuarine biotic environment (structural and functional proxies) for each site and year is summarised in Table 1. In general, the values for the total number of species differed among sites and years. For 1998, 2005 and 2006, respectively, the species number values were 19, 19 and 46 for the euhaline part of estuary; 6,32 , and 22 for the polyhaline sand-mud site (PSM); 14, 22, and 28 for the polyhaline muddy sand (PMS) (both PSM and PMS belong to the south-arm subsystem); and 8,18 and 21 for the north-arm polyhaline sand. These values were consistent with the behaviour of other structure related metrics, such as species richness (d), diversity $\left(H^{\prime}\right)$, total biomass, and the EQS, which tended to increase gradually after 1998. The species abundance presented a relatively stable pattern when considering the Mondego estuary as a whole, but significant differences could be observed among habitats and reaches. There was a substantial decrease in invertebrate species abundance in the polyhaline sand-mud area, which contributed to a decrease in the species number of the South arm.

\subsection{Linking ecosystem functioning to stability and services}

Within the invertebrate benthic communities (Table 1), there was an increase in the \% of trophic groups usually associated with better environmental conditions (e.g., grazers or suspension feeders). The results showed an increase in the \% of all trophic groups, concomitant with an increase in the system's biodiversity (captured through diversity measures). The macrobenthic P/B ratio decreased from 2005 to 2007 , however, from 63.74 to $29.89 \mathrm{y}^{-1}$ in the Mondego estuary as a whole and showed a similar pattern in most of the estuarine reaches (Table 1). A sudden productivity drop was observed in 2007 for most of the estuarine areas, except the polyhaline muddy-sand area, which showed relatively stable productivities. The species abundance increased from 92 to 159 individuals $\mathrm{m}^{-2}$ from 1998 to 2006 . The benthic biomass was similar in 2005 and 2006 and clearly higher than that for 1998.

A decrease in estuarine stability was observed over the years (Table 1), except for the polyhaline muddy-sand area, where an increase occurred.

\subsection{Linking changes in services to human well-being}

The Spearman correlation coefficients calculated between the pairs of abiotic, structural, and functional indicators are given for the three periods in Table 2. These relationships between factors varied strongly by year. In 1998 , the sediment characteristics were correlated with community functioning (Table 2). Mainly depending on the abiotic conditions, different functional groups (such as SDF or G species) dominate the benthic fauna assemblages. In general, the correlation between functional and structural indicators, as well as between different structural indicators, was positive. In contrast, different functional indicators were usually negatively correlated with one another (e.g., SF species with G or SDF species), with the exception of the productivity values among years, which showed an identical pattern as between structural and functional indicators. 
Table 1

Structural, functional and stability indicators of biodiversity in the Mondego estuary.

\begin{tabular}{|c|c|c|c|c|c|c|c|c|c|c|c|c|c|c|}
\hline & \multicolumn{2}{|l|}{ Unit } & \multicolumn{4}{|l|}{$\mathrm{ME}$} & \multicolumn{4}{|l|}{$\mathrm{EE}$} & \multicolumn{4}{|l|}{ PSM } \\
\hline & & & 1998 & 2005 & 2006 & 2007 & 1998 & 2005 & 2006 & 2007 & 1998 & 2005 & 2006 & 2007 \\
\hline \multicolumn{15}{|l|}{ Structural indicators } \\
\hline Ecological quality status & EQS & & M & 6 & 6 & - & - & - & - & - & - & - & - & - \\
\hline Number of species & $\mathrm{S}$ & & 30 & 49 & 70 & - & 19 & 19 & 46 & - & 6 & 32 & 22 & - \\
\hline (Shannon-Wiener index) & $H^{\prime}$ & & 1.61 & 2.52 & 2.74 & - & 2.48 & 3.07 & 3.22 & - & 1.43 & 2.46 & 1.99 & - \\
\hline (Margalef index) & d & & 1.01 & 2.23 & 2.07 & - & 1.65 & 3.46 & 3.15 & - & 0.94 & in & 1.70 & - \\
\hline Total abundance & $\mathrm{N}$ & & 5515 & 5878 & 4147 & - & 432 & 182 & 560 & - & 224 & 1965 & 828 & - \\
\hline Total biomass & bi & & 7.01 & 26.84 & 26.83 & - & 2.29 & 2.07 & 9.91 & - & 0.05 & 12.94 & 4.63 & - \\
\hline \multicolumn{15}{|l|}{ Functional indicators } \\
\hline Grazers & G & $\%$ & 14.13 & 26.04 & 31.79 & - & 17.54 & 45.07 & 29.11 & - & 19.09 & 15.91 & 18.60 & - \\
\hline Surface Deposit feeders & SDF & $\%$ & 80.61 & 35.00 & 43.27 & - & 28.07 & 39.44 & 46.58 & - & 80.91 & 21.73 & 26.95 & - \\
\hline Subsurface Deposit feeders & Ssdf & $\%$ & 3.58 & 36.14 & 20.32 & - & 53.51 & 12.68 & 20.55 & - & 0.00 & 55.24 & 53.36 & - \\
\hline Suspension feeders & $\mathrm{SF}$ & $\%$ & 1.68 & 2.74 & 4.42 & - & 0.88 & 2.82 & 3.77 & - & 0.00 & 7.12 & 1.09 & - \\
\hline Macrobenthic productivity & $\mathrm{mP}$ & $\mathrm{y}^{-1}$ & - & 63.74 & 67.34 & 29.89 & - & 5.21 & 2.31 & 2.15 & & 29.01 & 40.41 & 4.18 \\
\hline \multirow{4}{*}{$\begin{array}{l}\text { Stability } \\
\text { Temporal stability }\end{array}$} & & & & & & & & & & & & & & \\
\hline & TS & $\mathrm{y}^{-1}$ & 0.59 & 2.36 & 1.43 & 0.62 & 0.20 & 0.08 & 0.05 & 0.10 & 0.01 & 2.62 & 0.91 & 0.22 \\
\hline & \multicolumn{2}{|l|}{ Unit } & \multicolumn{4}{|l|}{ PMS } & \multicolumn{4}{|l|}{ PS } & \multicolumn{4}{|l|}{ SA } \\
\hline & & & 1998 & 2005 & 2006 & 2007 & 1998 & 2005 & 2006 & 2007 & 1998 & 2005 & 2006 & 2007 \\
\hline \multicolumn{15}{|l|}{ Structural indicators } \\
\hline Ecological quality status & EQS & & - & - & - & - & - & - & - & - & 6 & 6 & $\mathrm{H}$ & - \\
\hline Number of species & s & & 14 & 22 & 28 & - & 8 & 18 & 21 & - & 14 & 39 & 39 & - \\
\hline (Shannon-Wiener index) & $H^{\prime}$ & & 1.41 & 2.63 & 3.10 & - & 1.25 & 2.07 & 2.26 & - & 1.41 & 2.57 & 2.73 & - \\
\hline (Margalef index) & d & & 0.87 & 1.96 & 1.93 & - & 0.68 & 1.60 & 1.61 & - & 0.88 & 2.23 & 1.86 & - \\
\hline Total abundance & $\mathrm{N}$ & & 4716 & 2060 & 2180 & - & 143 & 1672 & 579 & - & 4940 & 4025 & 3008 & - \\
\hline Total biomass & bi & & 4.43 & 10.28 & 11.88 & - & 0.23 & 1.55 & 0.41 & - & 4.49 & 23.21 & 16.51 & - \\
\hline \multicolumn{15}{|l|}{ Functional indicators } \\
\hline Grazers & G & $\%$ & 12.83 & 44.31 & 37.53 & - & 51.13 & 12.44 & 43.13 & - & 13.05 & 32.00 & 30.49 & - \\
\hline Surface Deposit feeders & SDF & $\%$ & 85.26 & 53.22 & 54.84 & - & 48.87 & 25.40 & 31.88 & - & 85.11 & 39.57 & 44.46 & - \\
\hline Subsurface Deposit feeders & Ssdf & $\%$ & 0.07 & 0.59 & 1.29 & - & 0.00 & 62.05 & 17.92 & - & 0.06 & 24.28 & 20.66 & - \\
\hline Suspension feeders & $\mathrm{SF}$ & $\%$ & 1.84 & 1.68 & 6.02 & - & 0.00 & 0.11 & 6.67 & - & 1.77 & 4.04 & 4.19 & - \\
\hline Macrobenthic productivity & $\mathrm{mP}$ & $\mathrm{y}^{-1}$ & - & 19.79 & 12.22 & 22.59 & - & 14.13 & 11.92 & 2.69 & - & 53.58 & 64.6 & 29.01 \\
\hline \multicolumn{15}{|l|}{ Stability } \\
\hline Temporal stability & TS & $\mathrm{y}^{-1}$ & 1.17 & 2.70 & 3.04 & 1.33 & 0.41 & 2.75 & 0.68 & 0.20 & 0.55 & 2.84 & 1.97 & 0.76 \\
\hline
\end{tabular}

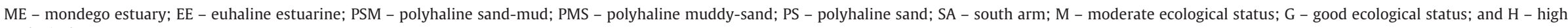
ecological status. 
Table 2

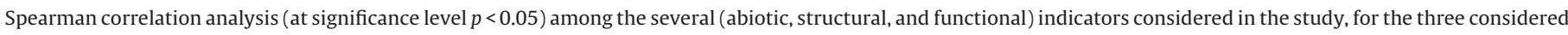
years (1998, 2005, and 2006).

\begin{tabular}{|c|c|c|c|c|c|c|c|}
\hline Abiotic indicators & Functional indicators & $r$ & Year & Structural indicators & Functional indicators & $r$ & Year \\
\hline \multirow{2}{*}{$\% \mathrm{O}_{2}$} & $\% \mathrm{G}$ & 0.9 & 1998 & \multirow[b]{2}{*}{ Biomass } & Prod. 2005 & 0.94 & 2005 \\
\hline & $\% s S D F$ & -0.96 & 1998 & & Prod. 2006 & 0.94 & 2005 \\
\hline \multirow{3}{*}{$\% \mathrm{OM}$} & $\% \mathrm{G}$ & -0.94 & 1998 & d & $\% \mathrm{SF}$ & 0.93 & 1998 \\
\hline & $\%$ SDF & 0.89 & 1998 & \multirow{4}{*}{$\mathrm{N}$} & Prod. 2005 & 0.94 & 2005 \\
\hline & $\% s S D F$ & 0.9 & 1998 & & Prod. 2006 & 0.94 & 2005 \\
\hline \multirow{3}{*}{$\%$ coarse sand } & \multirow{2}{*}{$\%$ SDF } & 0.94 & 1998 & & Prod. 2006 & 0.94 & 2006 \\
\hline & & -0.94 & 2005 & & Prod. 2007 & 1.00 & 2006 \\
\hline & & 0.94 & 2005 & \multirow{3}{*}{$\mathrm{S}$} & $\% \mathrm{SF}$ & 0.91 & 1998 \\
\hline \multirow[t]{2}{*}{ \%fine sand } & $\%$ SDF & 0.94 & 2006 & & Prod. 2005 & 0.94 & 2005 \\
\hline & $\% \mathrm{SF}$ & -0.94 & 2005 & & Prod. 2006 & 0.94 & 2005 \\
\hline $\mathrm{NH}_{3}$ & $\%$ SDF & 0.94 & 2006 & \multirow[t]{2}{*}{ EQS } & \multirow{2}{*}{$\% \mathrm{G}$} & 0.89 & 2005 \\
\hline POM & $\%$ SDF & 0.94 & 2006 & & & 1.00 & 2005 \\
\hline \multirow[t]{2}{*}{ SST } & $\%$ SDF & 0.94 & 2006 & \multirow[t]{2}{*}{$H^{\prime}$} & \multirow{2}{*}{$\% \mathrm{SF}$} & 0.93 & 1998 \\
\hline & $\% \mathrm{G}$ & 0.94 & 1998 & & & -0.94 & 2005 \\
\hline $\mathrm{O}_{2}$ & $\% s S D F$ & -0.99 & 1998 & Functional Indicators & Functional Indicators & r & year \\
\hline Temperature & $\%$ SDF & 1.00 & 1998 & \multirow{4}{*}{$\% \mathrm{G}$} & \multirow{2}{*}{$\% \mathrm{SF}$} & -0.94 & 2005 \\
\hline Structural Indicators & Structural Indicators & r & year & & & -0.89 & 2006 \\
\hline \multirow{3}{*}{ Biomass } & & 0.94 & 1998 & & \multirow{2}{*}{$\% s S D F$} & -0.99 & 1998 \\
\hline & $\mathrm{N}$ & 0.89 & 2005 & & & 1.00 & 2006 \\
\hline & $\mathrm{S}$ & 1.00 & 2005 & $\%$ SDF & $\% \mathrm{SF}$ & -0.89 & 2005 \\
\hline \multirow{4}{*}{ d } & \multirow{2}{*}{$\mathrm{S}$} & 0.93 & 1998 & $\% \mathrm{SF}$ & $\%$ SSDF & -0.89 & 2006 \\
\hline & & 0.93 & 2006 & Prod. 2005 & Prod 2006 & 1.00 & 2005 \\
\hline & \multirow{2}{*}{$H^{\prime}$} & 1.00 & 1998 & \multirow[t]{5}{*}{ Prod 2006} & \multirow[t]{5}{*}{ Prod 2007} & \multirow[t]{5}{*}{0.94} & \multirow[t]{5}{*}{2006} \\
\hline & & 0.94 & 2006 & & & & \\
\hline $\mathrm{N}$ & $\mathrm{S}$ & 0.89 & 2005 & & & & \\
\hline S & & 0.93 & 1998 & & & & \\
\hline EQS & $H^{\prime}$ & 0.89 & 2005 & & & & \\
\hline
\end{tabular}

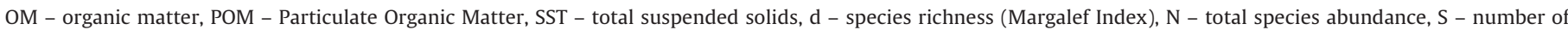

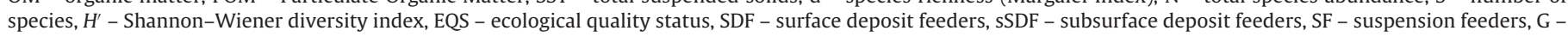
grazers, Prod. - productivity.

Four main services (water quality, eco-tourism, nursery grounds and food production) were found to directly influence or depend upon biodiversity assets (Table 3). A gradual increase in the water quality and eco-tourism services was identified over the years, whereas nursery grounds and food production services tended to decrease (Dolbeth et al., 2008; Pinto et al., 2010). In an opposing trend, two main constraints were identified that could influence the productivity of the estuary: species competition (mostly macrophytes vs. macroalgae) and habitat loss (mainly $Z$. noltii meadows area reduction), which both demonstrated decreasing trends (Table 3 ).

The available data show that the bivalve population is an important part of the estuarine community in terms of biomass, abundance, energy and material fluxes, in some years, accounting for as much as half of the total abundance or biomass ('ecosystem stocks' as available estuarine natural capital) (Fig. 3A). The importance of bivalves was particularly clear in 2007, when there was a significant drop in bivalve densities (due to reduced recruitment by the relevant species; Veríssimo et al., 2012).

After accounting for the number of boats dedicated to the capture of different species from bivalves to fish, there appeared to be a general decrease in this proxy for these resources catches on the estuary over time (Fig. 3B). Examination of the bivalve catch (data source: www.dgpa.min-agricultura.pt), however, revealed a trend towards increased productivity from 1995 to 2006, and the number of bivalves brought to the

Table 3

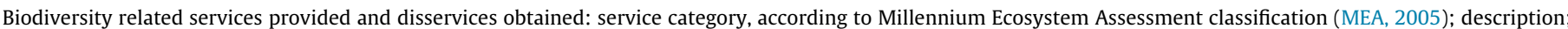
indicators used; and trends over the years.

\begin{tabular}{|c|c|c|c|c|c|}
\hline & Service category & Description & Indicators & Trend & References \\
\hline \multicolumn{6}{|c|}{ Biodiversity related services } \\
\hline Water quality & Regulating & $\begin{array}{l}\text { Filtering, retention and storage of } \\
\text { water proper for uses }\end{array}$ & $\begin{array}{l}\text { Dissolved nutrients } \\
\text { concentration }\end{array}$ & Increasing & Pinto et al., 2013b \\
\hline Eco-tourism & Cultural & $\begin{array}{l}\text { Estuarine resources/spaces with } \\
\text { (potential) recreational uses }\end{array}$ & Number of visitors & Increasing & $\begin{array}{l}\text { Data source: Sinergiae } \\
\text { Ambiente (data year: 2008) } \\
\text { PDM, } 2005\end{array}$ \\
\hline Nursery grounds & Supporting & $\begin{array}{l}\text { Suitable } \\
\text { reproduction/development habitat }\end{array}$ & $\begin{array}{l}\text { Fish productivity }\left(\mathrm{y}^{1}\right) \\
(2004-2006)\end{array}$ & Decreasing & Dolbeth et al., 2008 \\
\hline Food production & Provisioning & $\begin{array}{l}\text { Transformation of solar energy into } \\
\text { biomass for consumption }\end{array}$ & $\begin{array}{l}\text { Salt production } \\
\text { Aquaculture production } \\
\text { Fish captures }\end{array}$ & Decreasing & Pinto et al., 2010 \\
\hline \multicolumn{6}{|c|}{ Biodiversity related constrains } \\
\hline Species competition & Supporting & $\begin{array}{l}\text { Ecosystem changes affect the } \\
\text { prevalence of one species over the } \\
\text { other }\end{array}$ & Macroalgae biomass & Decreasing & Patrício et al., 2009 \\
\hline Habitat loss & Supporting & $\begin{array}{l}\text { Suitable living space for wild } \\
\text { plants and animals }\end{array}$ & Area occupied byZ. noltii & Decreasing & Patrício et al., 2009 \\
\hline
\end{tabular}

\footnotetext{
a Data source.
} 


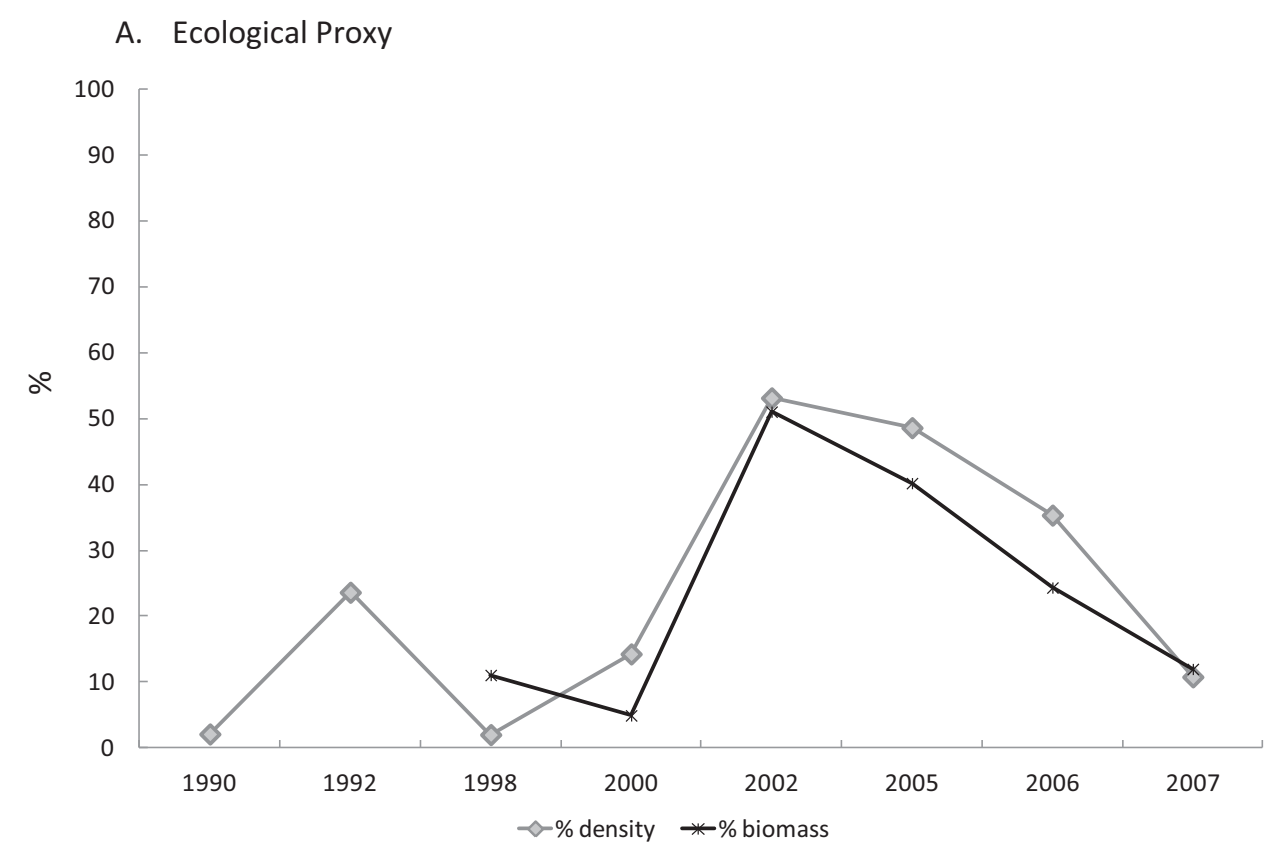

B. Economic Proxy

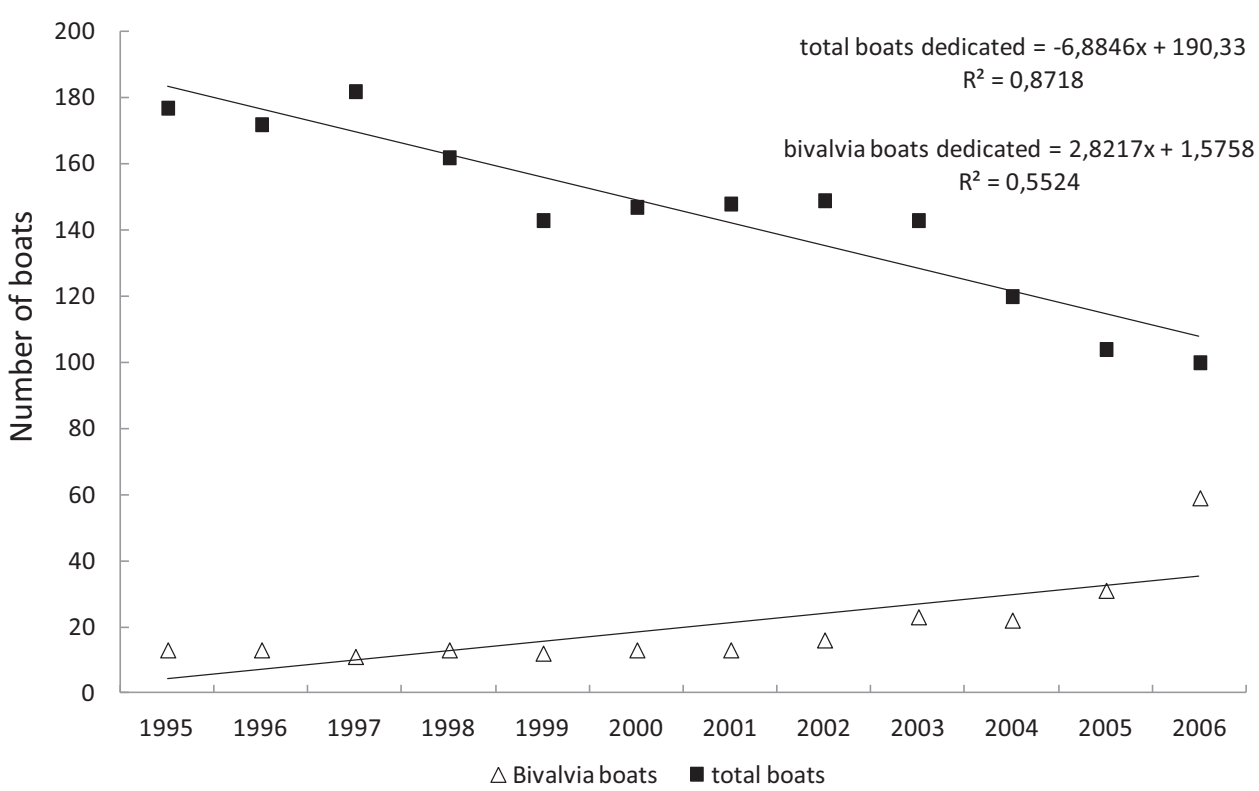

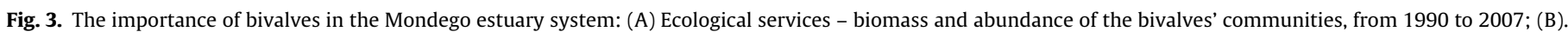
The number of boats involved in catching bivalves, from 1995 to 2006 (data source: www.dgpa.min-agricultura.pt).

Figueira da Foz harbour suggests an increase in catch from 2005 to 2006 (from circa 170 to 260 tonnes). Moreover, approximately 6 tonnes of bivalves were manually removed from the system in 2005, which would require approximately 120 persons partially dedicated to the harvest (data source: www.dgpa.min-agricultura.pt) and illustrating the importance of the bivalves for locals.

\section{Discussion}

Ecosystem services can be regarded as the (conceptual) link between the natural resources and social benefits that foster human well-being (Díaz et al., 2011). There have been efforts to relate biodiversity components with services provision, but only a few studies have been able to establish useful indicators (Díaz et al., 2007; NEA, 2010; Mace et al., 2012; van Oudenhoven et al., 2012). Turner et al. (2003) report that there is a strong interdependence between biodiversity and services provision, and there is additional current evidence that net ES value diminishes with biodiversity and ecosystem loss (Balmford et al., 2002; Jones-Walters and Mulder, 2009). Therefore, if biodiversity is positively correlated with ES delivery, then greater biodiversity may, or even, will increase the value of ecosystem services (Morling et al., 2010).

The conceptual framework adopted by MEA (2005) was further developed in the present work to address (with inherent natural and anthropogenic disturbances) the effects that biodiversity may have on the provision of the ES in environmentally 
dynamic systems of high socio-economic value, such as estuaries. Through the application of this framework, a quantitative and qualitative assessment of the relationships between ecological quality and ES provision was undertaken, aiming to achieve a better guide to the potential (future) management of estuarine ecosystems.

\subsection{Linking estuarine biodiversity to ecosystem functioning}

Even small losses of estuarine species may hinder the ability of ecosystems to adjust to change or maintain their functional level. Recent assessments have shown that global biodiversity loss preferentially affects species with longer life spans, bigger bodies, poorer dispersal capacities, more specialised resource uses, lower reproductive rates, and other traits that make them more susceptible to human pressures (e.g., by land occupation or nutrient release) (McKinney and Lockwood, 1999; Baillie et al., 2004; Mace et al., 2005; Díaz et al., 2006). Application of these global findings to this estuarine ecosystem demonstrated that stronger system perturbations lead to changes in all the structural proxies considered, with greater consequences for species diversity (decrease in number of species) and biomass. Moreover, previous work on the intertidal habitats of this estuarine system has shown that macrobenthic populations react to disturbances by a change in their biomasses. Studies with food web models, Baeta et al. (2011) have demonstrated that there was an increase in biomass, consumption, respiration and flow to detritus in Scrobicularia plana and Hediste diversicolor (two key species in the system) after the implementation of mitigation measures. In contrast, S. plana showed evidence of decreasing biomass and flows after the extreme winter flood of 2001 (Baeta et al., 2011).

The implicit relations between estuarine biodiversity and stability proxies may be useful indicators of the general functioning of these ecosystems, a conclusion that is consistent with previous empirical evidence (e.g.,Duffy, 2006). In fact, the ecosystems functional approach must be complemented with the analysis of its inherent properties. In the specific case of the Mondego estuary, it became clear that knowledge about the internal functioning of the system does not always decrease uncertainty about the system responses to ecological conditions. It was possible to demonstrate that functional indicators (e.g., species feeding guilds) respond directly (either positively or negatively) to changes in abiotic conditions and to structural and even to other functional metrics (e.g., variation in species feeding guilds ratios); however, structural proxies and overall system productivity were strongly related to one another but showed no significant relations with abiotic and functional metrics. This finding may suggest that while community structure directly determines part of the system productivity, the internal system functioning (e.g., \% of feeding guilds) is more vulnerable to changes in the surrounding environment (either abiotic or biotic variations). Several authors claim that it is the connectance of the system that plays a key role in the complexity-stability relationship, rather than the number of components within it (e.g. Jørgensen, 2002). In this sense, systems under-connected or over-connected would be more unstable (MacArthur, 1971; Levin, 1974; O'Neill et al., 1986), emphasising that stability maximisation is obtained at intermediate connectivity levels. In this context, the framework adopted in this study should be complemented with a detailed analysis of the food web energy flows within the communities, using, for instance, ecological network analysis (ENA) (Ulanowicz, 1980, 1986; Fath, 2004). The ENA approach is considered a promising method to analyse the functioning and judge the quality of ecosystems (de Jonge et al., 2012). Therefore, it is crucial to adopt an integrated perspective of system functioning, which can be achieved by evaluating and comparing the information and responses obtained from several proxies when facing different types of disturbances.

\subsection{Linking ecosystem functioning with stability and services provision}

Pinto et al. (2013a) illustrated that up to a certain limit estuarine stability and productivity seem to increase concomitantly with an increasing number of species and larger biomasses. On the other hand, previous works by, e.g., Elmqvist et al. (2003) and Naeem et al. (2009) suggest that a large number of species per functional groups, including rare species, may act as 'insurance' that buffers ecosystem processes and their derived services when changes occur in the surrounding physical and biological environment (e.g., temperature changes). Nevertheless, these ideas need to be experimentally tested (Carpenter et al., 2009). In the present work, the stability metric analysis allowed testing of the spatial and temporal responses of an estuarine system in relation to the 'insurance' role. The results indicate that estuarine stability could be reduced by environmental perturbation (e.g., eutrophication symptoms in 1998 or bivalve recruitment in 2007), which also affected total estuarine macrobenthic productivity. These findings are consistent with previous results for this system, which indicated concomitant trends of decreasing connectivity and increasing temporal stability for intertidal habitats (Pinto et al., 2013a). The inner parts of the estuary (e.g., South arm) were more stable and productive than were areas with higher water circulation or more exposure to adverse conditions, such as dredging activities (e.g., estuarine mouth-EE and PS). Therefore, this study is consistent with previous reports (e.g., Loreau et al., 2002; Díaz et al., 2006) that argue the existence of a strong relationship between species composition and ecosystems function, reinforcing the important role of biodiversity in ecosystem productivity and stability.

Species composition was a key factor strongly influencing estuarine functioning, which confirms previous research (e.g., Grime, 1997; Duffy, 2006). In fact, a negative relationship was found between stability and the occurrence of species feeding on surface deposits, which are usually considered to be ecologically important species because of their effect on sediment structure (bioturbation behaviour) (e.g., Van Colen et al., 2010). Although the concept of functional groups may be a valuable tool for simplifying community complexity, especially for management purposes (Gaston et al., 1998), the information acquired may be subject to criticism (e.g., difficulty in assigning species to feeding guilds or generalising trophic groups; Giangrande et al., 2000). To address this issue, information about the functional groups was coupled with macrobenthic productivity and stability measures, which, in general, showed a gradual increase. The productivity drop observed in 2007 was mainly caused by a reduction in the biomass of only one species (C. edule) (values in spring decreased from $11.94 \mathrm{~g} \mathrm{AFDW}^{-2}$ in 2005 to $0.020 \mathrm{~g} \mathrm{AFDW} \mathrm{m}^{-2}$ in 2007). However, the productivity method used was specifically designed for intertidal benthic communities (Brey, 2001), meaning that even assuming the validity of the subtidal parameter and the depth factor used to construct the model, some residual variance might be associated with these values.

\subsection{Linking changes in services to human well-being}

Estuarine biodiversity (including number of species, diversity, and total biomass) had a determinant role in the provision of ecosystem services and, consequently, on human well-being. Regarding the structural, functional and service relationships, the empirical evidence indicates that changes in benthic biodiversity (expressed by diversity measures) clearly affected ecosystem functioning (as shown in Table 1), in terms of both the intensity and the direction 
of the responses (e.g., the achievement of better ecological status). In fact, the loss of ecological complexity/linkages (Mace et al., 2012) is driving the world's ecosystems to a more frequent failure of their functions and services, even to an increased risk of unexpected and irreversible changes in their status (MEA, 2005). However, more efforts are needed in order to find the set of indicators, able to integrate the socio-ecological conditions of an ecosystem. In fact, quoting Braat and de Groot (2012), indicators are needed 'that are not only relevant and able to convey the message of the consequences of biodiversity loss, but must also be based on accepted methods that reflect the aspects of biodiversity involved in the service that is of interest, capture the often non-linear and multi-scale relationships between ecosystems and the benefits that they provide, be convertible into economic terms'.

The linkages between biodiversity, ecosystem functioning and ES provision for human well-being are neither straightforward nor universal. Although the connections between ecosystem properties and ES are not always linear causal paths (e.g. Carpenter et al., 2009; Pinto et al., 2013b), many changes in ES provision can be quantified by using variation in ecosystem properties recorded by routine measurements (Díaz et al., 2007; de Jonge et al., 2012). Therefore, the initial conceptual framework, which was the basis for this work (MEA, 2005), should be modified by the addition of reverse arrows to include the reciprocal effects that human well-being and ES provision have on estuarine biodiversity and ecosystem functioning:

biodiversity $\rightleftarrows$ ecosystem functioning $\rightleftarrows$ ecosystem services $\rightleftarrows$ human well-being

This study was undertaken in a medium-sized estuary having a strong local focus, so the extrapolation of these results for application to other estuarine systems may be limited. Nevertheless, the obtained results show that the multi-functionality of estuaries plays a determinant role both to biodiversity and human wellbeing, where several noteworthy trends were observed:

(1) Increasing species richness and functional composition had positive effects on estuarine productivity;

(2) Changes in estuarine ES provision are related to altered structural and abiotic factors and to the loss or decline of locally abundant species;

(3) The causes of change in underlying biodiversity and ecosystem functioning determines the system's ability to provide the associated ES; and

(4) Estuarine services, such as water quality improvement, revealed to play a crucial play on the ecosystem, not only due to its direct implications to biodiversity status, but also because it has both direct political consequences (i.e. fees applied to all member countries that do not achieve a Good Quality Status for water bodies until 2015, determined by the EC; EC, 2000) and social implications (i.e. local, and even national, populations are willing to see the water status improved, due to the benefits they would achieve from it and to safeguard the resource for biodiversity sake; Pinto et al., 2012; personal communication).

The current study showed that biodiversity management is able to affect the provision of valued ecosystem services, mainly provisioning, regulating and cultural services, since it can act as an important regulator for most of the ecosystems functional attributes. In fact, other studies performed at a landscape level (e.g., Kandziora et al., 2013), have shown that biodiversity has different roles depending on the type of service considered: (1) it can act as a structural limitation factor for regulating services; (2) can be a negative factor for some provisioning services, and (3) can make cultural services highly dependent on structural variables. In this study, these relations were not explored in detail, however, the previous described trends have demonstrated the crucial role that biodiversity assets had on services flows in estuarine ecosystems.

The key issue when addressing complex ecosystem management is to accurately translate ecosystem changes into measures that address both ES provision and ecosystem conservation. Adequate societal responses to improvements in ecological conditions require quantitative assessment of the biodiversity composition and ES consequences of changing environmental conditions (MEA, 2005; Hooper et al., 2005; Díaz et al., 2011; Mace et al., 2012), for example, through surveys (Contingent Valuation or Choice Experiments Methods) of affected populations.

The framework proposed in this study implies to accomplish both a functional and a commodity point of view upon natural ecosystems. As highlighted previously, the relations between biodiversity - ecosystem functioning - services provision, as well as the establishment of thresholds in natural processes that guarantee ecosystems sustainability, are difficult to determine and evaluate. An effort to establish conceptual links among these factors was performed; however, further in-depth research in establishing these links is not only justified but even necessary.

\section{Conclusions}

The findings of this study highlight a series of qualitative conclusions about the relation between biodiversity assets and human well-being in estuarine systems:

(1) the species composition of estuarine communities was a key factor that strongly affected system functioning;

(2) the complexity of the relationships between biodiversity and human well-being, via the effects and causes determining the ES provision; and

(3) changes in the estuarine ES provision likely derive from changing structural and abiotic factors and from the loss or decline of locally abundant species.

The results suggest two additional conclusions:

(1) more integrative tools/studies are required to explain the interactions of estuarine ecosystems with surrounding socioeconomic activities; and

(2) these tools need to be incorporated into decision-making processes aimed at the conservative management of ecosystems and used by institutions, particularly to guide the implementation of sustainable frameworks (integrating biodiversity assets and ecosystem services used for human well-being).

New research needs to accomplish several objectives:

(1) to further explain the links between biodiversity and ES provision in estuarine systems;

(2) clarify the functional role (achieved through connections among species) of macrobenthic species in the provision of valued ES (e.g., C sequestration); and

(3) elucidate the using of ecosystem production as a tool to guarantee that the consumption of natural resources is sustainable.

\section{Acknowledgements}

The present work was prepared within the scope of the research project 3M-RECITAL (LTER/BIA-BEC/0019/2009). Additionally, it benefited from one grant, attributed by FCT (SFRH/BPD/90675/2012). 


\section{References}

Anderson, B.J., Armsworth, P.R., Eigenbrod, F., Thomas, C.D., Gillings, S., Heinemeyer, A., Roy, D.B., Gaston, K.J., 2009. Spatial covariance between biodiversity and other ecosystem service priorities. J. Appl. Ecol. 46, 888-896.

Baeta, A., Niquil, N., Marques, J.C., Patrício, J., 2011. Modelling the effects of eutrophication, mitigation measures and an extreme flood event on estuarine benthic food webs. Ecol. Model. 222, 1209-1221.

Baillie, J.E.M., Hilton-Taylor, C., Stuart, S.N., 2004. IUCN Red List of Threatened Species: A Global Species Assessment. IUCN, Gland (Switzerland).

Balmford, A., Bruner, A., Cooper, P., Costanza, R., Farber, S., Green, R.E., Jenkins, M., Jefferiss, P., Jessamy, V., Madden, J., Munro, K., Myers, N., Naeem, S., Paavola, J., Rayment, M., Rosendo, S., Roughgarden, J., Trumper, K., Turner, R.K., 2002. Economic reasons for conserving wild nature. Science 297, 950-953.

Balvanera, P., Pfisterer, A.B., Buchmann, N., He, J.-S., Nakashizuka, T., Raffaelli, D., Schmid, B., 2006. Quantifying the evidence for biodiversity effects on ecosystem functioning and services. Ecol. Lett. 9, 1146-1156.

Barbier, E.B., Hacker, S.D., Kennedy, C., Koch, E.W., Stier, A.C., Silliman, B.R., 2011. The value of estuarine and coastal ecosystem services. Ecol Monog. 81 (2), 169-193.

Bennett, E.M., Balvanera, P., 2007. The future of production systems in a globalized world. Front.Ecol. Environ. 5, 191-198.

Braat, L.C., de Groot, R., 2012. The ecosystem services agenda: bridging the worlds of natural science and economics, conservation and development, and public and private policy. Ecosyst. Services 1 (1), 4-15

Brey, T., Jarre-Teichmann, A., Borlich, O., 1996. Artificial neural network versus multiple linear regression: predicting $\mathrm{P} / \mathrm{B}$ ratios from empirical data. Mar. Ecol. Prog. Ser. 140, 251-256.

Brey, T., 2001. Population Dynamics in Benthic Invertebrates. A virtual handbook. Alfred Wegener Institute for Polar and Marine Research, Germany, Version 01.2. http://www.awi-bremerhaven.de/Benthic/Ecosystem/FoodWeb/Handbook/ main.html

Borja, A., Franco, J., Pérez, V., 2000. A marine biotic index to establish the ecological quality of soft-bottom benthos within European estuarine and coastal environments. Mar. Pollut. Bull. 40 (12), 1100-1114.

Burkhard, B., Kroll, F., Nedkov, S., Muller, F., 2012. Mapping ecosystem service supply, demand and budgets. Ecol. Ind. 21, 17-29.

Carpenter, S.R., Mooney, H.A., Agard, J., Capistrano, D., DeFries, R.S., Díaz, S., Dietz, T., Duraiappah, A.K., Oteng-Yeboah, A., Pereira, H.M., Perrings, C., Reid, W.V., Sarukhan, J., Scholes, R.J., Whyte, A., 2009. Science for managing ecosystem services: beyond the millennium ecosystem assessment. Proc. Natl. Acad. Sci. U. S. A. 106 (5), 1305-1312.

Convention for Biological Diversity, 2004. How the Convention on Biological Diversity promotes nature and human well-being? Secretariat of the Convention on Biological Diversity with the support of the United Nations Environment Program (UNEP) and the Government of the United Kingdom.

Costanza, R., d'Arge, R., de Groot, R., Farber, S., Grasso, M., Hannon, B., Limburg, K., Naeem, S., O’Neill, R.V., Paruelo, J., Raskin, R.G., Sutton, P., van den Belt, M., 1997. The value of the world's ecosystem services and natural capital. Nature 387 , 253-260.

Costanza, R., Low, B.S., Ostrom, E., Wilson, J., 2001. Institutions, Ecosystems, and Sustainability. CRC Press, pp. 270p.

Cusson, M., Bourget, E., 2005. Global patterns of macroinvertebrate production in marine benthic habitats. Mar. Ecol. Prog. Ser. 297, 1-14.

Daily, G.C., 1997. Nature's Services: Societal Dependence on Natural Ecosystems. Island Press, Washington, DC, USA.

Desroy, N., Warembourg, C., Dewarumez, J.M., Dauvin, J.C., 2002. Macrobenthic resources of the shallow soft-bottom sediments in the eastern English Channel and Southern North Sea. ICES J. Mar. Sci. 60, 120-131.

Díaz, S., Fargione, J., Stuart Chapin III, F., Tilman, D., 2006. Biodiversity loss threatens human well-being. PLoS Biol. 4 (8), e277.

Díaz, S., Lavorel, S., de Bello, F., Quétier, F., Grigulis, K., Robson, T.M., 2007. Incorporating plant functional diversity effects in ecosystem service assessments. Proc. Natl. Acad. Sci. U.S.A. 104, 20684-20689.

Díaz, S., Quétier, F., Cáceres, D.M., Trainor, S.F., Pérez-Harguindeguy, N., BretHarte, M.S., Finegan, B., Peña-Claros, M., Poorter, L., 2011. Linking functional diversity and social actor strategies in a framework for interdisciplinary analysis of nature's benefits to society. Proc. Natl. Acad. Sci. U.S.A. 108 (3), 895-902.

Dolbeth, M., Lillebø, A.I., Cardoso, P.G., Ferreira, S.M., Pardal, M.A., 2005. Annual production of estuarine fauna in different environmental conditions: an evaluation of the estimation methods. J. Exp. Mar. Biol. Ecol. 326, 115-127.

Dolbeth, M., Martinho, F., Viegas, I., Cabral, H., Pardal, M.A., 2008. Estuarine production of resident and nursery fish species: conditioning by drought events? Estuar. Coast. Shelf Sci. 78, 51-60.

Duffy, J.E., 2006. Biodiversity and the functioning of seagrass ecosystems. Mar. Ecol. Prog. Ser. 311, 233-250.

EC, 2000. Directive 2000/60/EC of European Parliament and of the Council of 23 October 2000 establishing a framework for community action in the field of water policy. Off. J. Eur. Comm. L327, 22/12/200:0001-0073.

Elmqvist, T., Folke, C., Nyström, M., Peterson, G., Bengtsson, J., Walker, B., Norberg, J., 2003. Response diversity, ecosystem change, and resilience. Front. Ecol. Environ. 1, 488-494.

Fauchald, K., Jumars, P.A., 1979. The diet of worms: a study of polychaete feeding guilds. Oceanogr. Mar. Biol. Annu. Rev. 17, 193-284.

Farber, S.C., Costanza, R., Wilson, M.A., 2002. Economic and ecological concepts for valuing ecosystem services. Ecol. Econ. 41, 375-392.
Fath, B.D., 2004. Network analysis in perspective: comments on 'WAND: an ecological network analysis user friendly tool'. Environ. Modell. Softw. 19, 341-343.

Fisher, B., Turner, R.K., Morling, P., 2009. Defining and classifying ecosystem services for decision making. Ecol. Econ. 68 (3), 643-653.

Flindt, M.R., Kamp-Nielsen, L., Marques, J.C., Pardal, M.A., Bocci, M., Bendoricchio G., Salomonsen, J., Nielsen, S.N., Jørgensen, S.E., 1997. Description of the three shallow estuaries: Mondego River (Portugal), Roskilde Fjord (Denmark) and the lagoon of Venice (Italy). Ecol. Model. 102, 17-31.

Gaston, G.R., 1987. Benthic polychaeta of the Middle Atlantic Bight: feeding and distribution. Mar. Ecol. Prog. Ser. 36, 251-262.

Garcia-Arberas, L., Rallo, A., 2002. Life cycle, demography and secondary production of the polychaete Hediste divesicolor in a non-polluted estuary in the Bay of Biscay. Mar. Ecol. 23, 237-251.

Gaston, G.R., Rakocinski, C.F., Brown, S.S., Cleveland, C.M., 1998. Trophic function in estuaries: response of macrobenthos to natural and contaminant gradients. Mar. Freshwat. Res. 49, 833-846.

Giangrande, A., Licciano, M., Pagliara, P., 2000. The diversity of diets in Syllidae (Annelida: Polychaeta). Cah. Biol. Mar 41, 55-65.

Glémarec, M., 1986. Ecological impact of an oil-spill: utilization of biological indicators. IAWPRC-NERC Conference, July 1985. IAWPRC J. 18, 203-211.

Godbold, J.A., Bulling, M.T., Solan, M., 2011. Habitat structure mediates biodiversity effects on ecosystem properties. Proc. R. Soc. B 278 (1717), 2510-2518.

Grall, J., Glémarec, M., 1997. Using biotic indices to estimate macrobenthic community perturbations in the Bay of Brest. Estuar. Coast. Shelf Sci. 44 (suppl. A), 43-53.

Grimm, V., Wissel, C., 1997. Babel, or the ecological stability discussion: an inventory and analysis of terminology and a guide for avoiding confusion. Oecologia 109 323-334.

Grime, J.P., 1997. Biodiversity and ecosystem functioning: the debate deepens. Science $277,1260-1261$

de Groot, R.S., Wilson, M.A., Boumans, R.M.J., 2002. A typology for the classification, description and valuation of ecosystem functions, goods and services. Ecol. Econ. 41, 393-408

Haines-Young, R.H., Potschin, M., 2010. The links between biodiversity, ecosystem services and human well-being. In: Raffaelli, D., Frid, C. (Eds.), Ecosystem Ecology: A New Synthesis. BES Ecological Reviews Series. CUP, Cambridge.

Heywood, V.H.(Ed.), 1995. The Global Biodiversity Assessment. United Nations Environment Programme. Cambridge University Press, Cambridge, pp. 1140.

Hooper, D.V., Chapin III, F.S., Ewel, J.J., Hector, A., Inchausti, P., Lavorel, S., Lawton, J.H Lodge, D.M., Loreau, M., Naeem, S., Schmid, B., Setälä, H., Symstad, A.J., Vandermeen, J., Wardle, D.A., 2005. Effects of biodiversity on ecosystem functioning: a consensus of current knowledge. Ecol. Monogr. 75, 3-35.

Isbell, F.I., Wayne, P., Wilsey, B.J., 2009. Biodiversity, productivity and the temporal stability of productivity: patterns and processes. Ecol. Lett. 12, 443-451.

Ives, A.R., Gross, K., Klug, J.L., 1999. Stability and variability in competitive communities. Science 286, 542-544.

Jones-Walters, L., Mulder, I., 2009. Valuing nature: the economics of biodiversity. J Nat. Conservat. 17, 245-247.

de Jonge, V.N., 1974. Classification of brackish coastal inland waters. Hydrobiol. Bull. 8, 29-39.

de Jonge, V.N., 2007. Toward the application of ecological concepts in EU coasta water management. Mar. Poll. Bull. 55, 407-414.

de Jonge, V.N., Pinto, R., Turner, K., 2012. Integrating ecological, economic and social aspects to generate useful management information under the EU Directives ‘Ecosystem Approach'. Ocean Coast. Manag. 68, 169-188.

Jørgensen, S.E., 2002. Integration of Ecosystem Theories: A Pattern, third ed. Kluwer Academic Publishers, The Netherlands, 420 pp.

Jorgensen, S.E., Costanza, R., Xiu, F.L., 2010. Handbook of Ecological Indicators for Assessment of Ecosystem Health, second ed., pp. 482 pp.

Kandziora, M., Burkhard, B., Müller, F., 2013. Interactions of ecosystem properties, ecosystem integrity and ecosystem service indicators - A theoretical matrix exercise. Ecol. Ind. 28, 54-78.

Lehman, C.L., Tilman, D., 2000. Biodiversity, stability, and productivity in competitive communities. Am. Nat. 156, 534-552.

Levin, S.A., 1974. Dispersion and population interactions. Am. Nat. 108, 207-228.

Limnologisk Metodik, 1992. In: Kobenhavns Universitet (Ed.), Ferskvandsbiologisk Laboratorium. Akademisk Forlag, Kobenhavn.

Loreau, M., Naeem, S., Inchausti, P., Bengtsson, J., Grime, J.P., Hetcor, A., Hooper, D.U. Huston, M.A., Raffaelli, D., Schmid, B., Timan, D., Wardle, D.A., 2001. Biodiversity and ecosystem functioning: current knowledge and future challenges. Science 294, 804-808.

Loreau, M., Naeem, S., Inchausti, P. (Eds.), 2002. Biodiversity and Ecosystem Functioning: Synthesis and Perspectives. Oxford University Press, Oxford.

MacArthur, R.H., 1955. Fluctuations of animal populations and a measure of community stability. Ecology 36, 533-536.

MacArthur, R.H., 1971. Patterns of terrestrial bird communities. In: Farner, D.S., King J.R. (Eds.), Avian Biology. Academic Press, New York, pp. 189-221.

Mace, G., Masundire, H., Baillie, J., Ricketts, T., Brooks, T., 2005. Biodiversity. In: Hassan, R., Scholes, R., Ash, N. (Eds.), Ecosystems and Human Well-Being: Current State and Trends: Findings of the Condition and Trends Working Group. Island Press, Washington (D.C.), pp. 77-122.

Mace, G.M., Bateman, I., 2011. Conceptual framework and methodology (ch. 2). In: UK National Ecosystem Assessment. The UK National Ecosystem Assessment: Synthesis of the Key Findings. UNEP-WCMC, Cambridge.

Mace, G.M., Norris, K., Fitter, A.H., 2012. Biodiversity and ecosystem services: a multilayered relationship. Trends Ecol. Evol. 27 (1). 
Mancinelli, G., Sabetta, L., Basset, A., 2005. Short-term patch dynamics of macroinvertebrate colonization on decaying reed detritus in a Mediterranean lagoon (Lake Alimini Grande, Apulia, SE Italy). Mar. Biol. 148, 271-283.

May, R.M., 1972. Stability and Complexity in Model Ecosystems. Princeton University Press, Princeton, N.J.

Margalef, D.R., 1958. Information Theory in Ecology. Gen. Syst. Yearb. 3, 36-71.

Margalef, R., 1963. On certain Unifying Principles in Ecology. Am. Nat. 97 (897), 357-374.

Marques, J.C., 2001. Diversity, biodiversity, conservation, and sustainability. Sci. World 1, 534-543.

Marques, J.C., Nielsen, S.N., Pardal, M.A., Jørgensen, S.E., 2003. Impact of eutrophication and river management within a framework of ecosystem theories. Ecol. Model. 166 (1-2), 147-168.

Martins, I., Pardal, M.A., Lillebø, A.I., Flindt, M.R., Marques, J.C., 2001. Hydrodynamics as a major factor controlling the occurrence of green macroalgal blooms in a eutrophic estuary: a case study on the influence of precipitation and river management. Estuar. Coast. Shelf Sci. 52, 165-177.

McKinney, M., Lockwood, J., 1999. Biotic homogenization: a few winners replacing many losers in the next mass extinction. Trends Ecol. Evol. 14, 450-453.

MEA, 2003. Millennium Ecosystem Assessment, Ecosystems and Human WellBeing: A Framework for Assessment. Island Press, Washington, DC

MEA, 2005. Millennium Ecosystem Assessment. Ecosystems and Human Well-being: Wetlands and Water Synthesis. Wold Resources Institute, Washington, DC, pp. $80 \mathrm{pp}$.

Morling, P., Comerford, E., Bateman, I., Beaumont, N., Bolt, K., van Soest, D., Vause, J., 2010. Biodiversity. UK NEA Economic Analysis Report., pp. 26 pp.

Naeem, S., 1998. Species redundancy and ecosystem reliability. Conservat. Biol. 12, 39-45.

Naeem, S., Bunker, D.E., Hector, A., Loreau, M., Perrings, C., 2009. Introduction: the ecological and social implications of changing biodiversity. An overview of a decade of biodiversity and ecosystem functioning research. In: Naeem, S., Bunker, D.E., Hector, A., Loreau, M., Perrings, C. (Eds.), Biodiversity, Ecosystem Functioning and Human Well-Being: An Ecological and Economic Perspective. Oxford University Press Inc., New York, pp. 3-13.

Naidoo, R., Balmford, A., Costanza, R., Fisher, B., Green, R.E., Lehner, B., Malcolm, T.R., Ricketts, T.H., 2008. Global mapping of ecosystem services and conservation priorities. Proc. Natl. Acad. Sci. U.S.A. 105 (28), 9495-9500.

NEA, 2010. UK National Ecosystem Assessment. Preliminary Synthesis and Progress Report on Status and Trends, 22 February 2010.

Neto, J.M., Flindt, M.R., Marques, J.C., Pardal, M.A., 2008. Modelling nutrient mass balance in a temperate macro-tidal estuary: implications to management. Estuar. Coast. Shelf Sci. 76, 175-185.

Norris, K., Bailey, M., Baker, S., Bradbury, R., Chamberlain, D., Duck, C., Edwards, M., Ellis, C.J., Frost, M., Gibby, M., Gilbert, J., Gregory, R., Griffiths, R., Harrington, L., Helfer, S., Jackson, E., Jennings, S., Keith, A., Kungu, E., Langmead, O., Long, D., Macdonald, D., McHaffie, H., Maskell, L., Moorhouse, T., Pinn, E., Reading, C., Somerfield, P., Turner, S., Tyler, C., Vanbergen, A., Watt, A., 2010. Chapter 4: Biodiversity in the Context of Ecosystem Services. UK National Ecosystem Assessment: Technical Report., pp. 42 pp.

Odum, E.P., 1959. Fundamentals of Ecology, second ed. Saunders, Philadelphia

O’Neill, R.V., DeAngelis, D.L., Wade, J.B., Allen, T.F.H., 1986. A Hierarchical Concept of Ecosystems. Princeton University Press, Princteon, NJ, USA.

Plano Director Murraceira (PDM), 2005. Proposta de Plano Director para a Ilha da Morraceira. Relatório final., pp. 106.

Patrício, J., Ulanowicz, R., Pardal, M.A., Marques, J.C., 2004. Ascendency as an ecological indicator: a case study of estuarine pulse eutrophication. Estuar. Coast. Shelf Sci. 60, 23-35.

Patrício, J., Neto, J.M., Teixeira, H., Salas, F., Marques, J.C., 2009. The robustness of ecological indicators to detect long-term changes in the macrobenthos of estuarine systems. Mar. Environ. Res. 68, 25-36.

Pearce, D.W., Moran, D., 1994. The Economic Value of Biodiversity. Earthscan, London.

Pimm, S., 1984. The complexity and stability of ecosystems. Nature 307, 321-326.

Pinto, R., Patrício, J., Baeta, A., Fath, B.D., Neto, J.M., Marques, J.C., 2009. Review and evaluation of estuarine biotic indices to assess benthic condition. Ecol. Ind. 9, $1-25$.
Pinto, R., Patrício, J., Neto, J.M., Salas, F., Marques, J.C., 2010. Assessing estuarine quality under the ecosystem services scope: ecological and socio-economic aspects. Ecol. Complex. 7, 389-402.

Pinto, R., Patrício, J., Abreu, P., Marta-Pedroso, C., Baeta, A., Franco, J., Domingos, T., Marques, J.C., 2012. Ecosystem Services and Ecological Status Improvement: Determinants of Willingness-to-Pay for Water Quality and its Role for Decision-Making. Personal Communication at the 4th International EcoSummit. Ecological Sustainability. Restoring the Planet's Ecosystem Services, Columbus, Ohio, USA, 30th September-05th October.

Pinto, R., de Jonge, V.N., Chainho, P., Costa, J.L., Marques, J.C., Patrício, J., 2013a. Temporal stability in estuarine systems: implications for ecosystem services provision. Ecol. Ind. 24, 246-253.

Pinto, R., de Jonge, V.N., Neto, J.M., Domingos, T., Marques, J.C., Patrício, J., 2013b. Towards a DPSIR driven integration of ecological value, water uses and ecosystem services for estuarine systems. Ocean Coast. Manag. 72, 64-79.

Remane, A., 1934. Die Brackwasserfauna. Zoolog. Anz. (suppl.) 7, 34-74.

Schwartz, M.W., Bringham, C., Hoeksema, J.D., Lyons, K.G., Mills, M.H., van Mantgem, P.J., 2000. Linking biodiversity to ecosystem function: implications for conservation ecology. Oecologia 122, 297-305.

Shannon, C.E., Wiener, W., 1963. The Mathematical Theory of Communication. University of Illinois Press, IL, Urbana, pp. 117 pp.

Srivastava, D.S., Vellend, M., 2005. Biodiversity-Ecosystem function research: Is it relevant to conservation. Annu. Rev. Evol. Syst. 36, 267-294.

Strickland, J.D.H., Parsons, T.R., 1972. A Practical Handbook of Seawater Analysis Bulletin of Fisheries Research Board of Canada, vol. 167., second ed., pp. 311 pp.

Teixeira, H., Salas, F., Neto, J.M., Patrício, J., Pinto, R., Veríssimo, H., Garcia-Charton, J.A., Marcos, C., Pérez-Ruzafa, A., Marques, J.C., 2008. Ecological indices tracking distinct impacts along disturbance-recovery gradients in a temperate NE Atlantic Estuary e guidance on reference values. Estuar. Coast. Shelf Sci. 80, $130-140$.

Teixeira, H., Neto, J.M., Patrício, J., Veríssimo, H., Pinto, R., Salas, F., Marques, J.C., 2009. Quality assessment of benthic macroinvertebrates under the scope of WFD. BAT, the Benthic Assessment Tool. Mar. Pollut. Bull. 58 (10), $1477-1486$

Tilman, D., 1999. The ecological consequences of changes in biodiversity: a search for general principles. Ecology 80 (5), 1455-1474.

Tilman, D., Polasky, S., Lehman, C., 2005. Diversity, productivity and temporal stability in the economies of humans and nature. J. Environ. Econ. Manag. 49, 405-426.

Tilman, D., Reich, P.B., Knops, J.M.H., 2006. Biodiversity and ecosystem stability in a decade-long grassland experiment. Nature 441, 629-632.

Turner, R.K., Paavola, J., Cooper, P., Farber, S., Jessamy, V., Georgiou, S., 2003. Valuing nature: lessons learned and future research directions. Ecol. Econ. 46 (3), 493-510.

Ulanowicz, R.E., 1979. Complexity, Stability and Self-organization in natural communities. Oecologia 43, 295-298.

Ulanowicz, R.E., 1980. An hypothesis on the development of natural communities. J. Theor. Biol. 85, 223-245.

Ulanowicz, R.E., 1986. A phenomenological perspective of ecological development. In: Poston, T.M., Purdy, R. (Eds.), Aquatic Toxicology and Environmental Fate, vol. 9. ASTM STP 921. American Society for Testing and Materials, Philadelphia, pp. 73-81.

Van Colen, C., Montserrat, F., Vincx, M., Herman, P.M.J., Ysebaert, T., Degraer, S., 2010 Macrobenthos recruitment success in a tidalflat: Feeding trait dependent effects of disturbance history. J. Exp. Mar. Biol. Ecol. 385, 79-84.

van Oudenhoven, A.P.E., Petz, K., Alkemade, R., Hein, L., de Groot, R.S., 2012. Framework for systematic indicator selection to assess effects of land management on ecosystem services. Ecol. Ind. 21, 110-122.

Veríssimo, H., Bremner, J., Garcia, C., Patrício, J., van der, L.P., Marques, J.C. 2012. Assessment of the subtidal macrobenthic community functioning of a temperate estuary following environmental restoration. Ecol. Ind. 23, 312-322.

Yachi, S., Loreau, M., 1999. Biodiversity and ecosystem productivity in a fluctuating environment: The insurance hypothesis. Proc. Natl. Acad. Sci. U.S.A. 96 (4), 1463-1468. 